PACS: $12.38 . \mathrm{Gc}$

\title{
CHIRAL FERMIONS ALGORITHMS IN LATTICE QCD
}

\author{
(D)Dafina Xhako ${ }^{1 *}$, (D) Rudina Zeqirllari ${ }^{2}$ \\ ${ }^{I}$ Department of Physics Engineering, Faculty of Mathematical Engineering and Physical Engineering, \\ Polytechnic University of Tirana, Tirana, Albania \\ ${ }^{2}$ Department of Physics, Faculty of Natural Sciences, University of Tirana, Tirana, Albania \\ *E-mail:dafinaxhako@yahoo.com \\ Received November 28, 2018; revised January 24, 2019; accepted January 26, 2019
}

The theory that explains the strong interactions of the elementary particles, as part of the standard model, it is the so-called Quantum Chromodynamics (QCD) theory. In regimes of low energy this theory it is formulated and solved in a lattice with four dimensions using numerical simulations. This method it is called the lattice QCD theory. Quark propagator it the most important element that is calculated because it contains the physical information of lattice QCD. Computing quark propagator of chiral fermions in lattice means that we should invert the chiral Dirac operator, which has high complexity. In the standard inversion algorithms of the Krylov subspace methods, that are used in these kinds of simulations, the time of inversion is scaled with the inverse of the quark mass. In lattice QCD simulations with chiral fermions, this phenomenon it is knowing as the critical slowing-down problem. The purpose of this work is to show that the preconditioned GMRESR algorithm, developed in our previous work, solves this problem. The preconditioned GMRESR algorithm it is developed in U(1) group symmetry using QCDLAB 1.0 package, as good "environment" for testing new algorithms. In this paper we study the escalation of the time of inversion with the quark mass for this algorithm. It turned out that it is a fast inversion algorithm for lattice QCD simulations with chiral fermions, that "soothes" the critical slowingdown of standard algorithms. The results are compared with SHUMR algorithm that is optimal algorithm used in these kinds of simulations. The calculations are made for 100 statistically independent configurations on 64 x 64 lattice gauge U(1) field for three coupling constant and for some quark masses. The results showed that for the preconditioned GMRESR algorithm the coefficient $\mathrm{k}$, related to the critical slowing down phenomena, it is approximately -0.3 compared to the inverse proportional standard law $(\mathrm{k}=-1)$ that it is scaled SHUMR algorithm, even for dense lattices. These results make more stable and confirm the efficiency of our algorithm as an algorithm that avoid the critical slowing down phenomenon in lattice QCD simulations. In our future studies we have to develop the preconditioned GMRESR algorithm in four dimensions, in SU (3) lattice gauge theory.

KEYWORDS: algorithms, chiral, critical-slowing, fermions, lattice, QCD

\section{АЛГОРИТМИ ХІРАЛЬНИХ ФЕРМІОНІВ У РЕШІТЧАСТІЙ КХД} Dafina Xhako ${ }^{1}$, Rudina Zeqirllari²

${ }^{1}$ Кафедра фізичної інженерії, факультет математичної інженерії та фізичного машинобудування, Політехнічний університет Тірани, Тірана, Албанія

${ }^{2}$ Кафедра фізики, Факультет природничих наук, Університет Тірани, Тірана, Албанія

Теорія, яка пояснює сильні взаємодії елементарних частинок, як частина стандартної моделі, це так звана теорія квантової хромодинаміки (КХД). У режимах малої енергії ця теорія формулюється і вирішується у чотирьох-вимірній решітці за допомогою чисельного моделювання. Цей метод називається решітчаста КХД-теорія. Кварк пропагатор є найважливішим обчислювальним елементом, оскільки він містить фізичну інформацію про КХД решітку. Обчислення пропагатору кварків хіральних ферміонів в решітці означає, що ми повинні інвертувати хіральний оператор Дірака, який має високу складність. У стандартних алгоритмах інверсії методами Крилова, які використовуються в цих моделях, час інверсії масштабується 3 оберненою масою кварків. У решітчастому КХД-моделюванні з хіральними ферміонами це явище відоме як критична проблема уповільнення. Метою даної роботи є показати, що розроблений нами попередній алгоритм GMRESR вирішує цю проблему. Запропонований алгоритм GMRESR розроблений у груповій симетрії U (1) за допомогою пакета QCDLAB 1.0, як хорошого «середовища» для тестування нових алгоритмів. У цій роботі досліджується збільшення часу інверсії від маси кварків для цього алгоритму. Виявилося, що це швидкий алгоритм інверсії для решітчастих КХД моделювань 3 хіральними ферміонами, що «заспокоює» критичне уповільнення стандартних алгоритмів. Результати порівнюються 3 алгоритмом SHUMR, який $\epsilon$ оптимальним алгоритмом, що використовується в цих видах моделювання. Розрахунки проводяться для 100 статистично незалежних конфігурацій на $64 \times 64$ решіточному калібровочному полі U(1) для трьох констант зв'язку і для деяких мас кварків. Отримані результати показали, що для попереднього алгоритму GMRESR коефіцієнт k, пов'язаний 3 критичними явищами уповільнення, становить приблизно - 0,3 порівняно зі зворотним пропорційним стандартним законом $(\mathrm{k}=-1)$, що він $€$ масштабованим алгоритмом SHUMR, навіть для щільних решіток. Ці результати роблять більш стабільними і підтверджують ефективність нашого алгоритму як такого, що дозволяє уникнути критичного явища уповільнення в решітчастих КХД-моделюваннях. У наших майбутніх дослідженнях ми розвинемо попередній алгоритм GMRESR у чотирьох вимірах, для решітчастої калібровочної теорії SU(3).

КЛЮЧОВІ СЛОВА: алгоритми, хіральність, критичні сповільнення, ферміони, решітки, КХД

Quantum Chromodynamics (QCD) is the quantum theory of strong interactions of particles like quarks and gluons. It studies the physics of strong interactions for different regimes of energy, from low to high regimes. At high energies since asymptotic freedom of quarks it is displayed [1], we can make perturbative calculations of QCD. At low energies it is displayed the quark confinement [1] where the coupling between quarks it is very strong. At these regimes we can make only non-perturbative calculations. One of the most powerful methods at this point it is the lattice regularization of gauge theories. It was proposed by Wilson in 1974 [2] as a lattice gauge theory that is formulated on a lattice with (C) Xhako D., Zeqirllari R., 2019 
four dimensions, in space and time, where fields of quarks are positioned at lattice sites and the gluon fields are positioned on the links connecting neighboring sites. Lattice QCD with chiral fermions is very important in development of the QCD theory. Thus, we have to formulate QCD with chiral fermions on the lattice; for this purpose, exist two main formulations: the domain wall fermions [3,4] and the overlap fermions [5, 6], which are closely related [7]. Specifically, the truncated overlap of domain wall fermions [8], as it is showed in [9] at any lattice spacing, it is equivalent to overlap fermions in four dimensions. To take physical information from these theories we have to calculate quark propagators, which are combined to takes meson, nucleon and other elementary particle propagators. So, the basic major computing problem in lattice QCD simulations with chiral fermions is the calculation of quark propagator.

\section{MATERIALS AND METHODS}

Since we have to simulate the lattice QCD theory with chiral fermions we can use the chiral Dirac operator that is in fact the Neuberger operator or the so-called overlap operator [10]. The calculation of the overlap quark propagator means that we have to solve large linear systems of the type:

$$
D \cdot x=b .
$$

In Eq. (1) operator $D \in \mathbb{C}^{N \times N}$ is a sparse and large matrix operator representing the overlap Dirac operator on a four-dimensional space-time lattice, $x \in \mathbb{C}^{N}$ is the quark propagator and $b \in \mathbb{C}^{N}$ the source of quark. Due to high complexity of this operator, generally, this problem requires very intensive computations and high computing power.

For the solution of large linear systems as expressed in (1), there are standard tested methods. The optimal methods for chiral fermions are those from the Krylov subspace methods [11] such as: GMRES (Generalized Minimal Residual) [11], CGNE (Conjugate Gradient on Normal Equation) [11], SHUMR (Shifted Unitary Minimal Residual) [11]. These algorithms considerably slowed down for light quarks and in some cases don't converges. The inversion time in the Krylov's inversion algorithms [12] escalate in a disproportionate proportion with the quark mass. This phenomenon it is called the critical slowdown of simulation algorithms in lattice QCD with chiral fermions. For this reason we use simulations of lattice gauge theory with $U(1)$ symmetry or the simulations of the Quantum Electrodynamics (QED), in a lattice with two dimensions, space and time lattice. The QED it is a good "environment" for testing new algorithms of QCD. In [13] we have developed a faster inversion algorithm used for chiral fermions, called the preconditioned GMRESR (Generalized Minimal Residual - Recursive) algorithm. The feature of our preconditioned part is that we used the relation between the overlap operator and the truncated overlap operator with finite extra dimension. For implementation of the preconditioned GMRESR algorithm, we have used a software called QCDLAB $[14,15]$ which is a package designed for lattice QCD simulations and new algorithms. Specifically, we used the QCDLAB 1.0 version (a free-shared package that can be downloaded from QCDLAB project homepage [16]) [14], which has the lattice Schwinger model because this model owns similar characteristic and algorithms with lattice QCD. The idea of the preconditioned part in a lattice QCD algorithm it is developed also in [17]. With our algorithm in lattice with two dimension, we gain a factor of 2 if we compare our results with [17] for the same quark mass tested. Also, with this algorithm we have calculated the propagator of the domain wall fermions, and we have used the truncated overlap of domain wall fermions, in this case in $2+1$ dimensions. Our new algorithm gives a significant contribution to the lattice QCD algorithms and it is a new code that it is added to the QCDLAB 1.0 package, in U(1) gauge field background. A typical test of the inversion algorithms is to study the convergence history of these algorithms, specifically the residual norm convergence. This test shows the graphical results of the residual norm of the algorithm with the number of the Dirac operator multiplications. Such kind of study for the preconditioned GMRESR algorithm we have done in [18].

In this paper, we bring another important study on the efficiency and speed of an algorithm in the numerical simulations of the lattice QCD with chiral fermions. It is the escalation of the algorithm with the quark mass. In the standard inversion algorithms of the Krylov subspace methods, the time $t$ of inversion of chiral Dirac operator is scaled with the inverse of the quark mass $m_{q}$ (in lattice unit)

$$
t \sim\left(m_{q}\right)^{k}
$$

where $k=-1$ and this phenomenon is known as the critical slowing down. An inversion algorithm will be optimal one if the coefficient $k \approx 0$, so totally independent from quark mass. Equation (2) in logarithmic scale will take the form:

$$
\log t \sim k \log m_{q} .
$$

To study this phenomenon in our case we have calculated for the preconditioned GMRESR algorithm and for the SHUMR algorithm the time of inversion of overlap operator (in seconds) for different quark masses. Simulations for this work were performed at the Polytechnic University of Tirana -grid cluster. The cluster consists of 6 node cluster for computing problems. Each node is an HP ProLiant DL320 Server with dual-core Intel Xeon 3040, 1.86GHz, 2GB RAM $+80 \mathrm{~GB}$ HDD and two Gigabit Ethernet cards. Total number of cores is 12. 


\section{RESULTS}

We have performed numerical calculations for 100 gauge field configurations in U(1) lattice gauge theory which are statistically independent. The coupling constant of the gauge field background has been tested for three values $\beta=1.0, \beta=1.1, \beta=1.2$ as sufficient values to finalize the obtained results, in $64 \mathrm{x} 64$ lattice volume. Using the three values of coupling constant, simulations were performed for heavy to light quarks at the range of values $m_{q}=[0.5$, $0.45,0.4,0.35,0.3,0.25,0.2,0.15,0.1,0.05,0.01]$, in lattice units, for each of them. We have done identical numerical calculations for both algorithms, the preconditioned GMRESR and the SHUMR. The numerical results of simulations are presented in Table 1, Table 2 and Table 3 for three tested values of the coupling constant, respectively $\beta=1.0$, $\beta=1.1, \beta=1.2$.

Table 1.

Inversion time of chiral operator for coupling constant $\beta=1.0$ in lattice $64^{2}$.

\begin{tabular}{|c|c|c|}
\hline $\begin{array}{l}\text { Quark Mass (in } \\
\text { Lattice Unit) }\end{array}$ & Algorithms & $\begin{array}{l}\text { Inversion Time (in } \\
\text { Seconds) }\end{array}$ \\
\hline \multirow[t]{2}{*}{0.5} & SHUMR & 110.47 \\
\hline & GMRESR & 43.120 \\
\hline \multirow[t]{2}{*}{0.45} & SHUMR & 120.42 \\
\hline & GMRESR & 42.800 \\
\hline \multirow[t]{2}{*}{0.4} & SHUMR & 142.83 \\
\hline & GMRESR & 42.830 \\
\hline \multirow[t]{2}{*}{0.35} & SHUMR & 184.15 \\
\hline & GMRESR & 43.080 \\
\hline \multirow[t]{2}{*}{0.3} & SHUMR & 208.04 \\
\hline & GMRESR & 45.230 \\
\hline \multirow[t]{2}{*}{0.25} & SHUMR & 256.73 \\
\hline & GMRESR & 46.840 \\
\hline \multirow[t]{2}{*}{0.20} & SHUMR & 369.05 \\
\hline & GMRESR & 47.030 \\
\hline \multirow[t]{2}{*}{0.15} & SHUMR & 689.95 \\
\hline & GMRESR & 50.180 \\
\hline \multirow[t]{2}{*}{0.1} & SHUMR & 1024.19 \\
\hline & GMRESR & 61.230 \\
\hline \multirow[t]{2}{*}{0.05} & SHUMR & 2843.24 \\
\hline & GMRESR & 90.910 \\
\hline \multirow[t]{2}{*}{0.001} & SHUMR & 13863.2 \\
\hline & GMRESR & 117.213 \\
\hline
\end{tabular}

Inversion time of chiral operator for coupling constant $\beta=1.1$ in lattice $64^{2}$.

Table 2 .

\begin{tabular}{|c|c|c|}
\hline $\begin{array}{l}\text { Quark Mass (in } \\
\text { Lattice Unit) }\end{array}$ & Algorithms & $\begin{array}{l}\text { Inversion Time (in } \\
\text { Seconds) }\end{array}$ \\
\hline 0.5 & SHUMR & 102.20 \\
\cline { 2 - 3 } & GMRESR & 40.430 \\
\hline \multirow{2}{*}{0.45} & SHUMR & 116.78 \\
\hline \multirow{2}{*}{0.4} & GMRESR & 41.630 \\
\cline { 2 - 3 } & SHUMR & 137.23 \\
\hline \multirow{2}{*}{0.35} & GMRESR & 42.130 \\
\hline \multirow{2}{*}{0.3} & SHUMR & 154.25 \\
\hline \multirow{2}{*}{0.25} & GMRESR & 42.660 \\
\hline \multirow{2}{*}{0.20} & GMUMR & 198.64 \\
\cline { 2 - 3 } & SHUMR & 43.930 \\
\hline \multirow{2}{*}{0.15} & GMRESR & 216.03 \\
\hline \multirow{2}{*}{0.1} & SHUMR & 44.100 \\
\cline { 2 - 3 } & GMRESR & 289.11 \\
\hline \multirow{2}{*}{0.05} & SHUMR & 45.130 \\
\hline & GMRESR & 410.17 \\
\hline \multirow{2}{*}{0.001} & GMUMR & 50.760 \\
\cline { 2 - 3 } & SHUMR & 919.65 \\
\hline & GMRESR & 61.530 \\
\hline & SHUMR & 2746.23 \\
\hline & GMRESR & 76.110 \\
\hline & & 118705.1 \\
\hline
\end{tabular}


Inversion time of chiral operator for coupling constant $\beta=1.2$ in lattice $64^{2}$.

Table 3.

\begin{tabular}{|c|c|c|}
\hline $\begin{array}{l}\text { Quark Mass (in } \\
\text { Lattice Unit) }\end{array}$ & Algorithms & $\begin{array}{l}\text { Inversion Time } \\
\text { (in Seconds) }\end{array}$ \\
\hline \multirow[t]{2}{*}{0.5} & SHUMR & 96.340 \\
\hline & GMRESR & 37.190 \\
\hline \multirow[t]{2}{*}{0.45} & SHUMR & 103.780 \\
\hline & GMRESR & 40.630 \\
\hline \multirow[t]{2}{*}{0.4} & SHUMR & 127.280 \\
\hline & GMRESR & 41.240 \\
\hline \multirow[t]{2}{*}{0.35} & SHUMR & 134.250 \\
\hline & GMRESR & 42.660 \\
\hline \multirow[t]{2}{*}{0.3} & SHUMR & 168.640 \\
\hline & GMRESR & 43.030 \\
\hline \multirow[t]{2}{*}{0.25} & SHUMR & 198.030 \\
\hline & GMRESR & 44.100 \\
\hline \multirow[t]{2}{*}{0.20} & SHUMR & 259.110 \\
\hline & GMRESR & 45.130 \\
\hline \multirow[t]{2}{*}{0.15} & SHUMR & 330.170 \\
\hline & GMRESR & 49.760 \\
\hline \multirow[t]{2}{*}{0.1} & SHUMR & 824.190 \\
\hline & GMRESR & 60.530 \\
\hline \multirow[t]{2}{*}{0.05} & SHUMR & 1446.24 \\
\hline & GMRESR & 76.110 \\
\hline \multirow[t]{2}{*}{0.001} & SHUMR & 9904.27 \\
\hline & GMRESR & 91.930 \\
\hline
\end{tabular}

In graphical form according (2) the results are showed in Figure 1, Figure 2 and Figure 3.

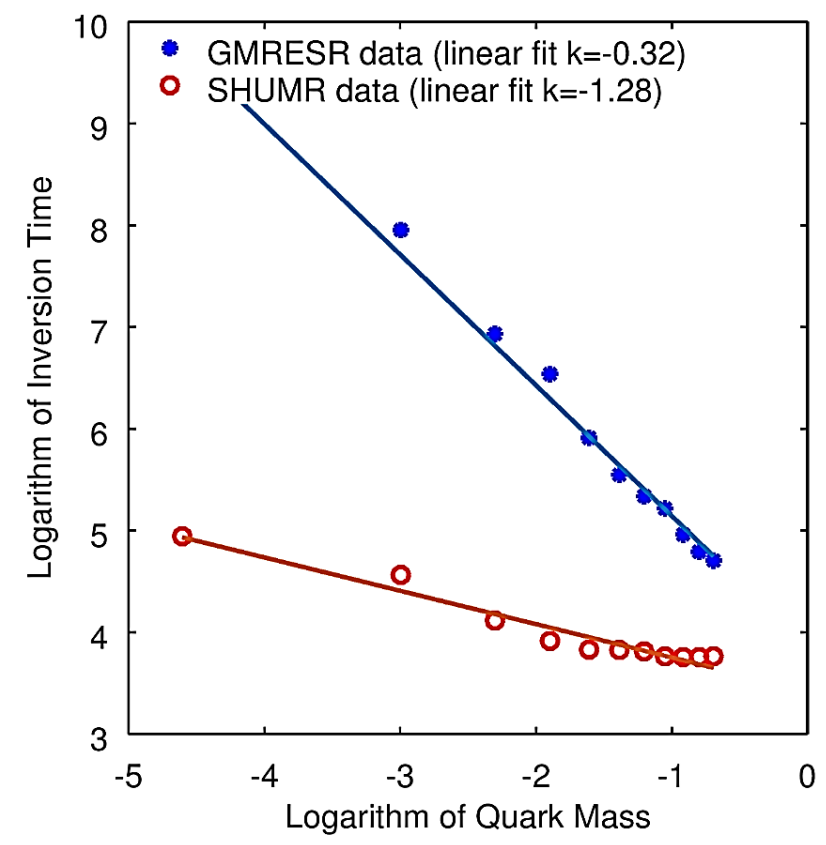

Fig. 1. The graphic of inversion time (in seconds) of the overlap chiral operator from the quark mass on the logarithmic scale using the preconditioned GMRESR and SHUMR algorithms, in $64 \times 64$ lattice with $U$ (1) gauge field and $\beta=1.0$. The linear fit of our data for the preconditioned GMRESR algorithm gives $\mathrm{k}=$ -0.32 and for SHUMR, $\mathrm{k}=-1.28$.

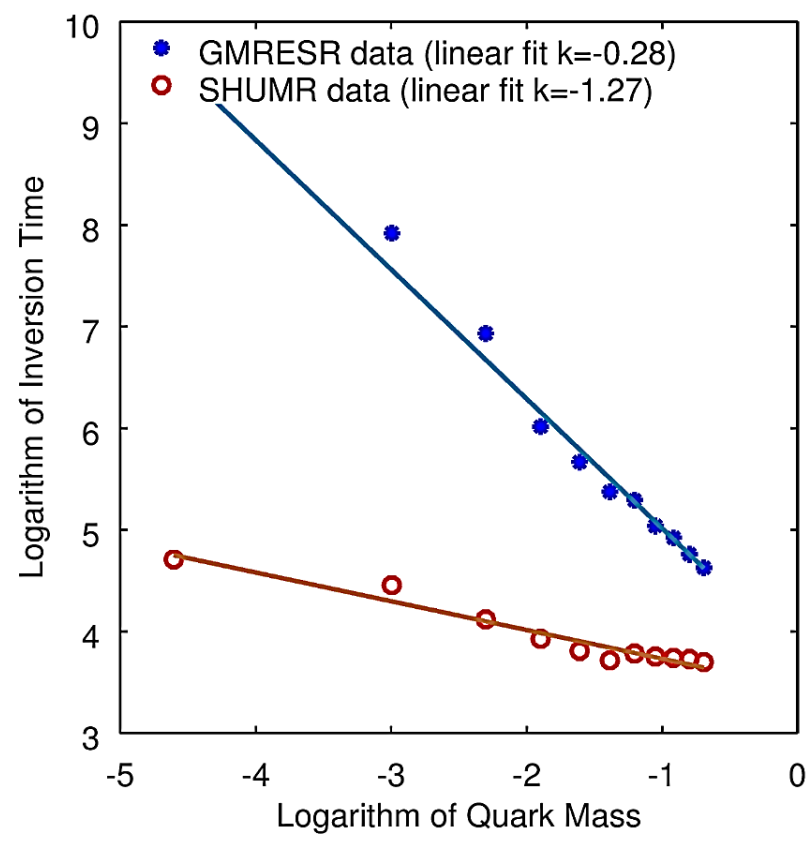

Fig. 2. The graphic of inversion time (in seconds) of the overlap chiral operator from the quark mass on the logarithmic scale using the preconditioned GMRESR and SHUMR algorithms, in $64 \times 64$ lattice with $U$ (1) gauge field and $\beta=1.1$. The linear fit of our data for the preconditioned GMRESR algorithm gives $\mathrm{k}=$ -0.28 and for SHUMR, $\mathrm{k}=-1.27$. 


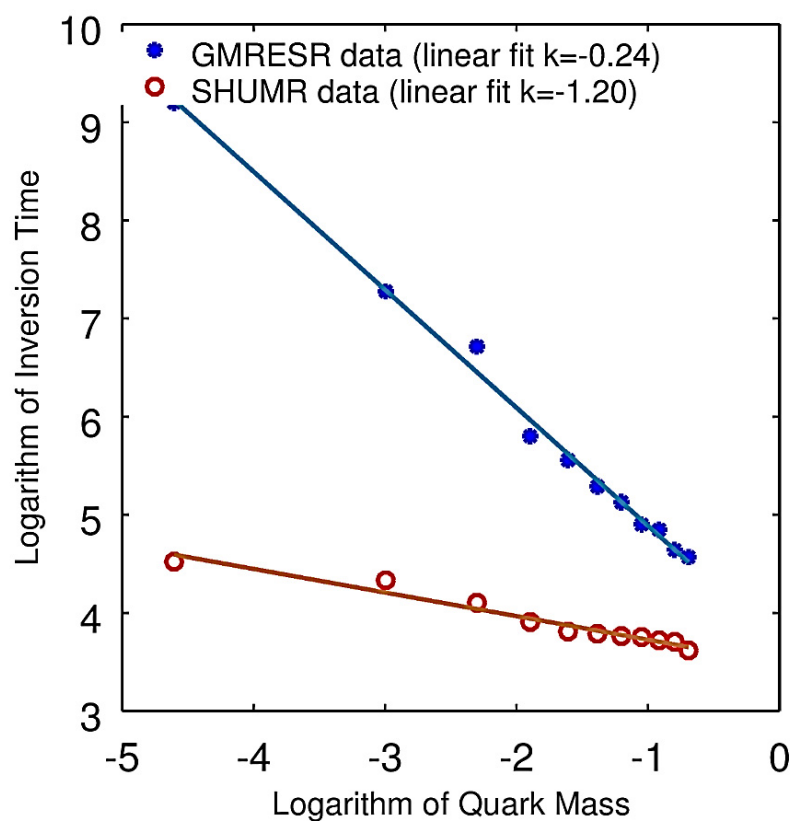

Fig. 3. The graphic of inversion time (in seconds) of the overlap chiral operator from the quark mass on the logarithmic scale using the preconditioned GMRESR and SHUMR algorithms, in 64x64 lattice with $U$ (1) gauge field and $\beta=1.2$. The linear fit of our data for the preconditioned GMRESR algorithm gives $\mathrm{k}=-0.24$ and for SHUMR, $\mathrm{k}=-1.20$.

Figure 1, Figure 2 and Figure 2 represents the graphics of inversion time (in seconds) of the overlap chiral operator from the quark mass for both algorithms. The graphics are on logarithmic scale in order to find the coefficient $k$. As we have explained above, we have used the preconditioned GMRESR and SHUMR algorithms, in 64 x 64 lattice with U (1) gauge field.

\section{DISCUSSIONS}

In Figure 1 the preconditioned GMRESR algorithm escalate with the quark mass as $\left(m_{q}\right)^{-0.32}$ and the SHUMR as $\left(m_{q}\right)^{-1.28}$. So, the coefficient $k$ for SHUMR algorithm is 4 times greater than for the preconditioned GMRESR algorithm for coupling constant $\beta=1$. In Figure 2 the preconditioned GMRESR algorithm escalate with the quark mass as $\left(m_{q}\right)^{-0.28}$ and the SHUMR as $\left(m_{q}\right)^{-1.27}$. So, the coefficient $k$ for SHUMR algorithm is 4.5 times greater than for the preconditioned GMRESR algorithm for coupling constant $\beta=1.1$. In Figure 3 the preconditioned GMRESR algorithm escalate with the quark mass as $\left(m_{q}\right)^{-0.24}$ and the SHUMR as $\left(m_{q}\right)^{-1.20}$. So, the coefficient $k$ for SHUMR algorithm is 5 times greater than for the preconditioned GMRESR algorithm for coupling constant $\beta=1.2$. So finally, the inversion time of chiral operator from the quark mass, in lattice QCD simulations, using the preconditioned GMRESR algorithm, doesn't escalate with the invers of quark mass as SHUMR algorithm. So, it "soothes" the critical slowing down of standard algorithms used in chiral simulations of lattice QCD.

\section{ACKNOWLEDGMENTS}

This work is done using the parallel computing system of the Faculty of Information Technology and with the support of the Department of Engineering Physics in the Faculty of Engineering Mathematics and Engineering Physics (FIMIF), Polytechnic University of Tirana, and the Department of Physics in the Faculty of Natural Science, University of Tirana, Albania.

Dafina Xhako (D) https://orcid.org/0000-0002-0937-2471,

Rudina Zeqirllari (D) https://orcid.org/0000-0002-0367-9560,

[1]. M. Lüscher, Annales Henri Poincare, 4, 197-210 (2003).

\section{REFERENCES}

[2]. K. G. Wilson, Phys. Rev. D, 10, 2445 (1974), doi: 10.1103/PhysRevD.10.2445.

[3]. D. B. Kaplan, Phys. Lett. B, 228, 342 (1992), doi: 10.1016/0370-2693(92)91112-M.

[4]. V. Furman and Y. Shamir, Nucl. Phys. B, 439, 54 (1995), doi: 10.1016/0550-3213(95)00031-M. 
[5]. R. Narayanan and H. Neuberger, Phys. Lett. B 302, 62 (1993), doi: 10.1016/0370-2693(93)90636-V.

[6]. R. Narayanan and H. Neuberger, Nucl. Phys. B 443, 305 (1995), doi: 10.1016/0550-3213(95)00111-5.

[7]. A. Boriçi, in: $Q C D$ and Numerical Analysis III Proceedings, edited by A. Boriçi, A. Frommer, B. Joó, A. Kennedy and B. Pendleton (Springer, Germany, 2005), pp. 25-39.

[8]. A. Boriçi, Nucl. Phys. Proc. Suppl. 83, 771 (2000), doi: 10.1016/S0920-5632(00)91802-4.

[9]. A. Boriçi, in: Lattice Fermions and Structure of the Vacuum, edited by V. Mitrjushkin and G. Schierholz, (Kluwer Academic Publishers, London, 2006), pp. 41-54.

[10]. H. Neuberger, Phys. Lett. B 417, 141 (1998), doi: 10.1016/S0370-2693(97)01368-3.

[11]. A. Boriçi, PhD thesis, No. CSCS TR-96-27, ETH Zurich (1996).

[12]. A. Boriçi and P. Forcrand, in: Physics Computing '94 Proceedings, edited by R. Gruber and M. Tomassini (European Physical Society, Switzerland, 1994), pp. 711-714.

[13]. D. Xhako and A. Boriçi, American Journal of Physics and Applications, 2, 67 (2014), doi: 10.11648/j.ajpa.20140202.15.

[14]. A. Boriçi, High Energy Physics - Lattice (hep-lat), (2006), arXiv:hep-lat/0610054.

[15]. A. Boriçi, Invited talk given at the: Domain Wall Fermions at Ten Years, 2007 March 15-17, Brookhaven National Laboratory, arXiv:hep-lat/0703021.

[16]. QCDLAB software, http://phys.fshn.edu.al/qcdlab.

[17]. N. Cundy, Comput. Phys. Commun. 165, 22 (1974), doi: 10.1016/j.cpc.2004.10.005.

[18]. D. Hyka (Xhako) and R. Osmanaj (Zeqirllari), in: 35 th International Symposium on Lattice Field Theory - Lattice 2017 Proceedings, edited by M. D. Morte, E. G. Sanchez, P. Fritzsch and C. P. Ruano, (EPJ Web of Conferences, France, 2018), pp. 14005-14061. 